\title{
POWER ASSESSMENT OF LOWER LIMBS AND STRENGTH ASYMMETRY OF SOCCER GOALKEEPERS
}

\author{
František Zahálka, Tomáš Malý, Lucia Malá, Tomáš Gryc, Pavel Hráský
}

Faculty of Physical Education and Sport, Charles University, Prague, Czech Republic

Submitted in April, 2013

\begin{abstract}
BACKGROUND: Effective execution of vertical jump depends on the explosive power of lower limbs and their symmetrical integration mainly. Assessment of lower extremity bilateral asymmetries in soccer players is important for both injury prevention and performance.

OBJECTIVE: The aim of this study was to identify and compare parameters of lower limb power in three different jump tests in elite soccer goalkeepers. The next aim was to describe and compare strength asymmetries of force exerted by lower limbs in the take-off phase in all tests.

METHOD: The research group consisted of 25 elite soccer goalkeepers (age $26.5 \pm 9.1$ years, height $186.1 \pm 7.8 \mathrm{~cm}$, weight $86.7 \pm 14.8 \mathrm{~kg})$. Three types of a vertical jump - countermovement jump with arms included $\left(\mathrm{CMJ}_{\mathrm{FA}}\right)$, countermovement jump with arms excluded (CMJ) and squat jump (SJ) were performed on two force platforms. Following parameters were assessed - maximum force during the take-off phase $\mathrm{F}_{\max }(\mathrm{N})$ and their relative value $\mathrm{F}_{\text {rel }}\left(\mathrm{N} \cdot \mathrm{kg}^{-1}\right)$, jump height $\mathrm{h}(\mathrm{m})$ and force asymmetry between limbs $\left(\Delta \mathrm{F}_{\max }\right)$. RM ANOVA was used in statistical analysis.

RESULTS: The type of jump had a significant effect on jump height $\left(F_{2,48}=109.66, p<.01, \eta^{2}=.82\right)$. The highest jump was reached in $\mathrm{CMJ}_{\mathrm{FA}}$. This result was higher by $11.1 \%(5.01 \mathrm{~cm})$ in comparison to $\mathrm{CMJ}$ and by $19.9 \%(8.98 \mathrm{~cm})$ than in SJ. Type of jump significantly influenced $\mathrm{F}_{\max }\left(F_{1.6,38.7}=44.29, p<.01, \eta^{2}=.65\right)$ and $\mathrm{F}_{\text {rel }}\left(F_{2,48}=50.33, p<.01\right.$, $\left.\eta^{2}=.68\right)$. Force asymmetry between limbs $\left(\Delta \mathrm{F}_{\max }\right)$ was significantly different with respect to the type of jump performed $\left(F_{1.3,31.7}=5.14, p<.05, \eta^{2}=.18\right)$. The highest force asymmetry was found in $\mathrm{CMJ}_{\mathrm{FA}}$ test $\left(\Delta \mathrm{F}_{\max }=8.61 \%\right)$, while the difference in CMJ test was $(7.06 \%)$ and in $\mathrm{SJ}$ test $\left(\Delta \mathrm{F}_{\max }=3.95 \%\right)$. We found a significantly greater difference in $\Delta \mathrm{F}_{\max }$ between $\mathrm{CMJ}_{\mathrm{FA}}$ vs. SJ $(p<.05)$ and $\mathrm{CMJ}$ vs. $\mathrm{SJ}(p<.01)$.

CONCLUSION: The best results of jump height were achieved, as expected in the $\mathrm{CMJ}_{\mathrm{FA}}$ but in this test also the greatest force asymmetry was detected. Monitoring of power level and strength asymmetries at the beginning of the preparatory period enables identification of possible strength imbalances in elite soccer goalkeepers, which should be further reduced during the preparatory period. Screening examination of strength asymmetry may be thus a useful tool for both performance and injury prevention in goalkeepers.
\end{abstract}

Keywords: Vertical jump, goalkeeper, soccer, symmetry, imbalance, injury prevention.

\section{INTRODUCTION}

A vertical jump is one of essential motor skills in many sports and its monitoring and description is based on both external movement structure and explosive strength of lower limbs as a basic driving impulse for its performance. The movement of the whole body during the take-off is very important aspect for a successful jump together with the high explosive strength of lower limbs. For movement evaluation from the viewpoint of kinematics it is necessary to set critical phases of the

\footnotetext{
* Address for correspondence: František Zahálka, Laboratory of Sports Motorics, Faculty of PhysicalEducation and Sport, Charles University, José Martího 31, 16252 Prague, Czech Republic E-mail: zahalka@ftvs.cuni.cz
}

body's movement (Janura, Vaverka, \& Elfmark, 1996). When performing the jump with arm swing, higher values of the vertical height are reached, which is the result of the upper limbs' work during the take-off, as well as braking and acceleration impulses conducted during the lowering phase and subsequent take-off (Bobbert, Gerritsen, Litjens, \& Van Soest, 1996). In terms of vertical position of the centre of mass, the jump can be divided and described by means of its individual phases. A countermovement jump with arm swing $\left(\mathrm{CMJ}_{\mathrm{FA}}\right)$ starts from an upright standing position with a preliminary downward movement by flexing at the lower limbs along with a slight forward flexion of the torso, the centre of mass moves down until it is in its lowest position. The countermovement ends in this stage. This phase is also called a braking phase. Since this moment, an acceleration phase begins, lower limbs extend and per- 
form the movement in the vertical direction and the whole phase is completed by the last contact of feet with the ground. The following flying phase ends with the first contact of tips with the ground. Subsequently, lower limbs absorbs landing by tips and knee flexion.

Proper and effective jump performance in soccer players, especially goalkeepers, is an essential component of soccer skills. Ioannis (2013) publish significant differences in power (squat jump, drop jump) with respect to performance level in Greek soccer players (higher division, middle division, lower division). Haughen, Tønnessen, and Seiler (2013) report significantly lower performance in countermovement jump (CMJ) test in midfielders by $5-6 \%$ compared to goalkeepers, forwards and defenders. Similarly, Boone, Vaeyens, Steyaert, Bossche, and Bourgois (2012) present significantly lower jump height in CMJ test in midfielders and full backs in comparison to goalkeepers, midfielders and forwards.

Positive effects of physical activity are well known and described in scientific literature. However, its excessive level may negatively reflects in some aspects of physical fitness in terms of various forms of maladaptation effects, strength or morphological imbalances. If these problems of the movement apparatus are not compensated starting in the youth population it can have a negative impact on further development. Assessment of lower extremity bilateral asymmetries in soccer players is important for both injury prevention (Fowler \& Reilly, 1993; Lehance, Binet, Bury, \& Croisier, 2009; Menzel, Chagas, Szmuchrowski, Araujo, Andrade, \& Jesus-Moraleida, 2013) and performance (Fousekis, Tsepis, \& Vagenas, 2010; Malý, Zahálka, \& Malá, 2011). The bilateral limb deficit describes the difference in maximal or near maximal force generating capacity of muscles when they are contracted alone or in combination with the contralateral muscles (Kuruganti \& Seaman, 2006). Although asymmetrical strength has been linked to a variety of pathological conditions or risk of injuries in field soccer players (Dauty \& Potiron-Josse, 2004; Rahnama, Lees, \& Bambaecichi, 2005; Rahnama, Reilly, Lees, \& Graham-Smith, 2003; Tourny-Chollet, Leroy, Leger, \& Beuret-Blanquart, 2000), no research results are available in terms of identification of strength imbalances during power assessment in elite soccer goalkeepers, who often prefer one leg to kick (kicking leg) and another to take-off (jumping leg). Lower limb bilateral strength asymmetries in soccer are the most frequently assessed using the isokinetic dynamometry method (Cometti, Maffiuletti, Pousson, Chatard, \& Maffulli, 2001; Kellis, Gerodimos, Kellis, \& Manou, 2001; Lehnert, Urban, Procházka, \& Psotta, 2011; Malý, Zahálka, \& Malá, 2010) but Menzel et al. (2013) suggest, based on results of factors analysis (forty-six elite
Brazilian soccer players), that the isokinetic testing and CMJ tests are widely independent methods for assessment of bilateral differences. Due to the above specified manifestation of goalkeeper's movement (jump), with the principle of high acceleration, jump testing can be considered more adequate than isokinetic strength where the movement speed is constant. To our best knowledge, no scientific literature evaluating power assessment and its asymmetry in larger group (> 20) of elite soccer goalkeepers (SG) was found.

\section{AIM}

The aim of this study was to identify and compare parameters of lower limb power in three different jump tests in elite SGs. The next aim was to describe and compare strength asymmetries of force exerted by lower limbs in the take-off phase in all tests.

\section{METHODS}

\section{Research group}

The research group consisted of 25 elite players, soccer goalkeepers $(n=25$, age $26.5 \pm 9.1$ years, body height $186.1 \pm 7.8 \mathrm{~cm}$, body weight $86.7 \pm 14.8 \mathrm{~kg}$ ). All SGs were players of the highest Czech soccer league (Gambrinus League). The players were tested at the beginning of the winter preparatory period (January) in 2009-2013. The research was approved by the Ethical committee of Faculty of Physical Education and Sport, Charles University in Prague. Measurement were carried out in accordance with ethical standards of Declaration of Helsinki and ethical standards in sport and exercise science research (Harriss \& Atkinson, 2011).

\section{Power and strength asymmetry assessment}

For recording force of lower limbs on the ground, two side-by-side mounted force platforms Kistler B8611A, $400 \mathrm{~Hz}$ (KISTLER Instrumente AG, Switzerland) were used. For data processing, BioWare 4.0.0 and Matlab R2013 software were used. For height of the jump, the calculation from force impulse was used. This procedure is based on force measurement and sequential calculation of velocity of Centre of Gravity. Height of the jump from take-off velocity was calculated by the equation $\left(\mathrm{h}=\mathrm{v}_{\text {take-off }} / 2 \cdot \mathrm{g}\right)$. All participants performed three types of a vertical jump - countermovement jump with arms included $\left(\mathrm{CMJ}_{\mathrm{FA}}\right)$, countermovement jump with arms excluded (CMJ) and squat jump (SJ). Each participant made three successful trials of each type of jump with a recovery interval of 60 seconds after each trial. For subsequent evaluation, only the best trial was chosen. Each participant was in an upright standing position on two force platforms to determine the force under each lower limb separately. 
The measured parameters were the maximal force during the take-off phase $\mathrm{F}_{\max }(\mathrm{N})$ and jump height $\mathrm{h}$ (m). Jump height was calculated from take-off speed. The maximum force $\mathrm{F}_{\text {max }}(\mathrm{N})$ during the take-off phase was assessed for each lower limb. Due to specific playing position, to assess muscular strength asymmetry we determined in each goalkeeper "kicking leg - KL" and "jumping leg - JL". This criterion was determined on the basis of an answer on the question which leg the goalkeeper uses for a goal kick. Force $\mathrm{F}_{\operatorname{maxkL}}(\mathrm{N})$ or $\mathrm{F}_{\text {maxiL }}(\mathrm{N})$ for lower limb separately was determined and subsequently it was converted to kilograms of players' body weight $\mathrm{F}_{\text {rel }}\left(\mathrm{N} \cdot \mathrm{kg}^{-1}\right)$. Level of asymmetry between lower limbs was calculated as ratio between separated relative forces in percentages (\%) as follows:

$$
\Delta \mathrm{F}_{\max }=\frac{\mathrm{JL} \text { score }-\mathrm{KL} \text { score }}{\mathrm{JL} \text { score }} \cdot 100(\%)
$$

\section{Statistical analysis}

Significant differences in the monitored parameters depending on the performed movement (type of the jump) were evaluated using repeated measures analysis of variance $(\mathrm{RM}$ ANOVA $1 \times 3)$ which compares the variance of within-groups effects. Determination of parameter significance between the individual jumps was then conducted using the multiple comparisons of means (Bonferonni's post-hoc test).

When the criterion of sphericity as one of the conditions of ANOVA, which was assessed using Mauchly's test $\left(\chi^{2}\right)$, was not met, degrees of freedom were adjusted by means of Greenhous-Geisser's (GG) sphericity correction and then the statistical significance was assessed according to particular degrees of freedom. Rejection of the null hypothesis was assessed at the level of $p<.05$. Effect size was assessed using the "Eta square" coefficient $\left(\eta^{2}\right)$ which explains the proportion of variance of the monitored factor.

\section{RESULTS}

During the evaluation of lower limb strength we found out that elite players formed a very homogenous group. In assessment of absolute jump height achieved, vertical jumps with arm swing are the most divergent from inter-individual perspective. Inclusion of upper limbs is in this type of jump was the most various among the players, even if comparable results in vertical jump were achieved.

The type of jump had a significant effect on jump height $\left(F_{2,48}=109.66, p<.01, \eta^{2}=.82\right)$. On the basis of measured and calculated data from three types of jumps, we may notice that the highest jump was achieved in the first type $\mathrm{CMJ}_{\mathrm{FA}}$ (Table 1). This result was higher by $11.1 \%(5.01 \mathrm{~cm})$ in comparison to the countermovement jump without arm swing (CMJ) and by $19.9 \%(8.98 \mathrm{~cm})$ than in the squat jump (SJ). Multiple comparisons of means showed a significant difference between different types of jumps $(p<.05)$ (Table 1).

An independent variable (type of jump) also significantly influence maximum force $\left(\mathrm{F}_{\max }\right)$ $\left(F_{1.6,38.7}=44.29, p<.01, \eta^{2}=.65\right)$ as well as relative force $\left(\mathrm{F}_{\text {rel }}\right)\left(F_{2,48}=50.33, p<.01, \eta^{2}=.68\right)$ exerted in the take-off phase. Bonferonni's post-hoc tests revealed insignificant difference between $\mathrm{CMJ}_{\mathrm{FA}}$ and $\mathrm{CMJ}$ tests $(p>.05)$ and significant differences in comparisons of $\mathrm{CMJ}_{\mathrm{FA}}$ and $\mathrm{CMJ}$ tests with SJ test $(p<.01)$. Force exerted by lower limbs expressed in percentage $\left(\Delta \mathrm{F}_{\max }\right)$ was significantly different with respect to the type of executed jump $\left(F_{1.3,31.7}=5.14, p<.05, \eta^{2}=.18\right)$. The highest strength asymmetry was found in $\mathrm{CMJ}_{\mathrm{FA}}$ test $\left(\Delta \mathrm{F}_{\max }=8.61 \%\right)$. When arms were excluded $(\mathrm{CMJ})$ the asymmetric difference was lower (7.06\%). The lowest difference of strength asymmetry was measured in $\mathrm{SJ}$ test $\left(\Delta \mathrm{F}_{\max }=3.95 \%\right)$. Bonferonni's post-hoc tests showed significantly greater difference in asymmetry between $\mathrm{CMJ}_{\mathrm{FA}}$ vs. SJ $(p<.05)$ and CMJ vs. SJ $(p<.01)$.

Figure 1 shows the force curve during the $\mathrm{CMJ}_{\mathrm{FA}}$ jump. At the beginning, the force value corresponds with participant's body weight. The take-off starts with a downward movement of the body (a) when active force is reduced (ideally to zero - (b)). The braking phase is from the moment when the force reaches back the value of the body weight (c) up to a maximum force. This is followed by a take-off impulse that ends with a zero value of the applied force and the participant leaves the ground (e). The landing is accompanied by a strong force impact with respect to absorbing (f). The Figure 2 shows the force curves of asymmetric jump that the jumping leg during the body lowering began to move earlier than the kicking leg (point a); at the moment of maximal force, the right leg was involved by $20 \%$ more than the left one.

\section{DISCUSSION}

To assess a vertical jump, the absolute height achieved is primarily used. Mean values of the monitored group ranged as follows $-\mathrm{CMJ}_{\mathrm{FA}}=45.07 \pm 3.22 \mathrm{~cm}$, $\mathrm{CMJ}=40.06 \pm 3.48 \mathrm{~cm}$ and $\mathrm{SJ}=36.09 \pm 3.42 \mathrm{~cm}$. In comparison to, for instance basketball players, they are lower; the study (Ziv \& Lidor, 2010) presents the following values $-\mathrm{CMJ}_{\mathrm{FA}}=61.0 \mathrm{~cm}, \mathrm{CMJ}=43.9 \mathrm{~cm}$ and $\mathrm{SJ}=39.8 \mathrm{~cm}$. Our participants' results in CMJ tests are comparable with the study by Haughen et al. (2013) who noted in goalkeepers $(N=45) \mathrm{CMJ}=39.8 \pm 4.2 \mathrm{~cm}$. The same authors present in the national Norwegian team $(N=21) \mathrm{CMJ}=39.4 \pm 5.2 \mathrm{~cm}$. The most remark- 


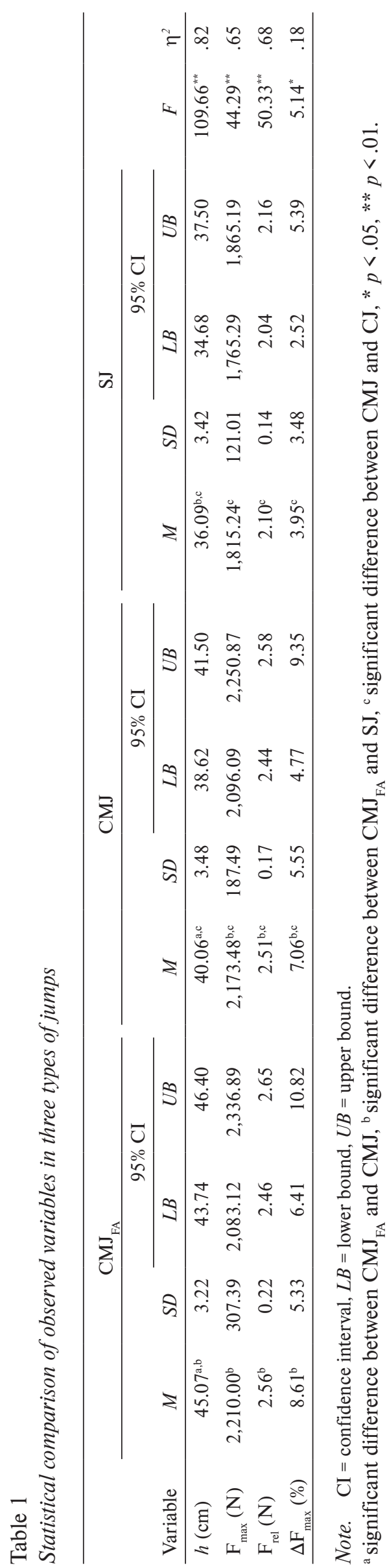

able difference is in a countermovement jump with arm swing $\left(\mathrm{CMJ}_{\mathrm{FA}}\right)$, where we can suggest that our monitored group has more reserves in lower limbs work. Effective work of upper limbs is very important in all types of take-off and it is a base for a successful jump (Svoboda, Janura, Cabell, \& Janurová, 2009). The proper arm swing during the take-off phase contributes to body propulsion; on the contrary, inappropriate position of upper limbs can cause the need for correction movements during the take-off or flight phases and thus eliminate the advantage gained. In basketball players, it is reasonable to expect high demands on upper limbs work during the maximal vertical jump, especially with regards to work with the ball in the area of a basket; increased concentration on development of upper limbs work in athletes is assumed from the viewpoint of complex focus on the entire body. The difference between the tested groups and our group is $26.1 \%$ compared to basketball players and $15.4 \%$ compared to athletes.

The height of jump and strength parameters $\left(\mathrm{F}_{\max }\right.$, $\mathrm{F}_{\text {rel }}$ ) were lower in SJ test than in jump height in $\mathrm{CMJ}_{\mathrm{FA}}$ and CMJ. It is the result of the use of eccentric muscle work in $\mathrm{CMJ}_{\mathrm{FA}}$ and $\mathrm{CMJ}$ tests. A muscle in eccentric contraction is able to produce greater power than in concentric contraction. Power output can be further increased in actions where eccentric contraction is immediately followed by concentric contraction of muscle groups where elastic characteristics of muscle are used (stretch-shortening cycle). When a muscle is stretched, specific mechanoreceptors located within the muscle (muscle spindle fibres) are also stretched and send feedback to central nervous system. This feedback causes an immediate signalling of the muscle fibres to contract to prevent potential tissue damage from overstretching (Kraemer \& Looney, 2012). In synchronous activity with character of concentric contraction this "stretch reflex" may cause higher rate of force development of the movement.

Jump height in $\mathrm{CMJ}_{\mathrm{FA}}$ was in comparison to $\mathrm{CMJ}$ test higher by $5.01 \mathrm{~cm}(11.1 \%)$. This fact can be confirmed by the study (Reiser, Rocheford, \& Armstrong, 2006) in which authors suggest that effective inclusion of upper limbs may improve the jump height by $25 \%$. In addition to absolute value of the jump, from our point of view, it is important to determine the influence of individual parameters affecting the jump height.

The total force developed on the ground $F_{\max }$ in $\mathrm{CMJ}_{\mathrm{FA}}$ varies for individual players on a larger scale; the minimum value $\mathrm{F}=1,788 \mathrm{~N}$ and maximum value $\mathrm{F}=2,533 \mathrm{~N}$; however, this can be the result of different participants' body weight because body weight is reflected into this parameter (the lower body weight was $75.7 \mathrm{~kg}$ and the highest body weight was $98.4 \mathrm{~kg}$ ). Impellizzeri, Rampinini, Maffiuletti, and Marcora (2007) report in CMJ test in 451 athletes bilateral difference 


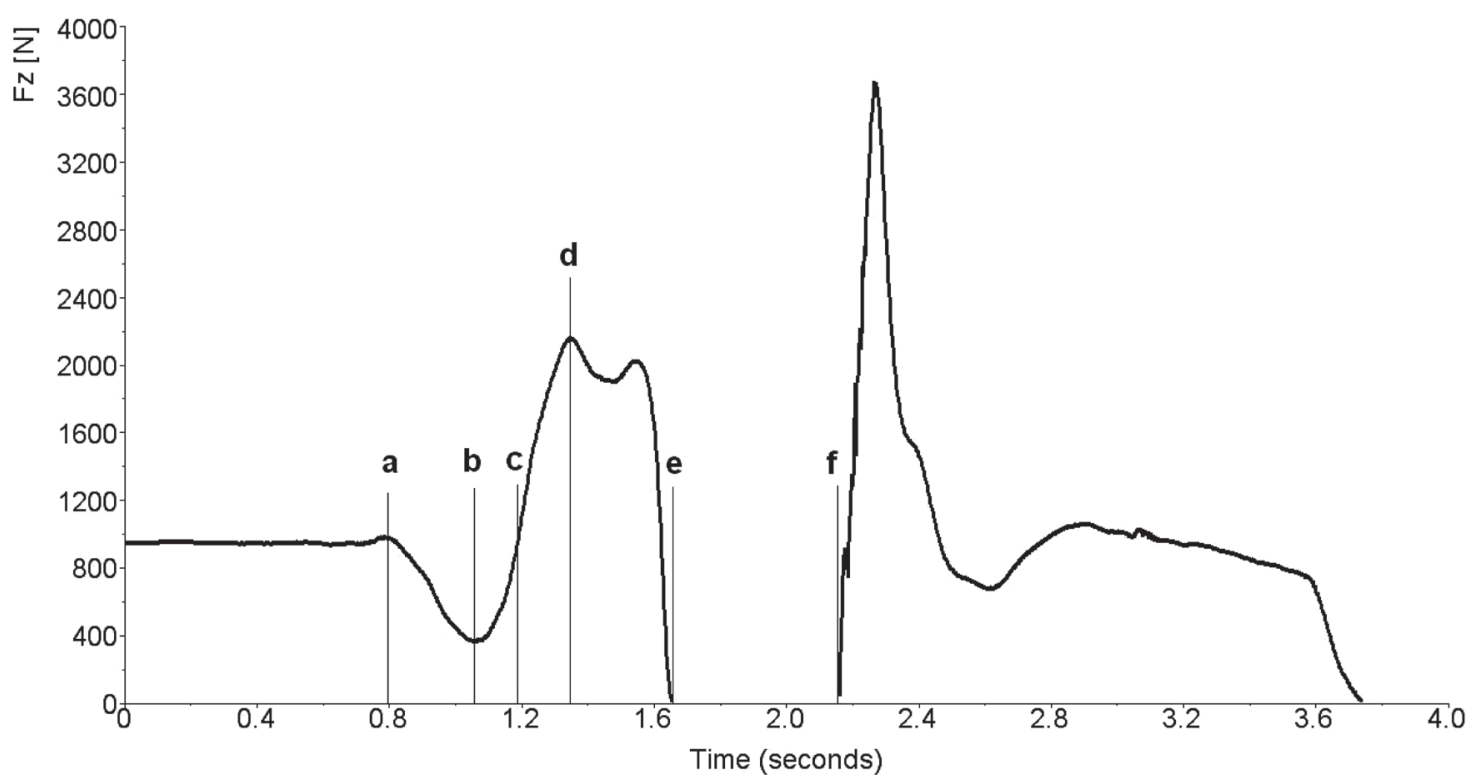

Figure 1. The force curve and phases during the $\mathrm{CMJ}_{\mathrm{FA}}$ jump

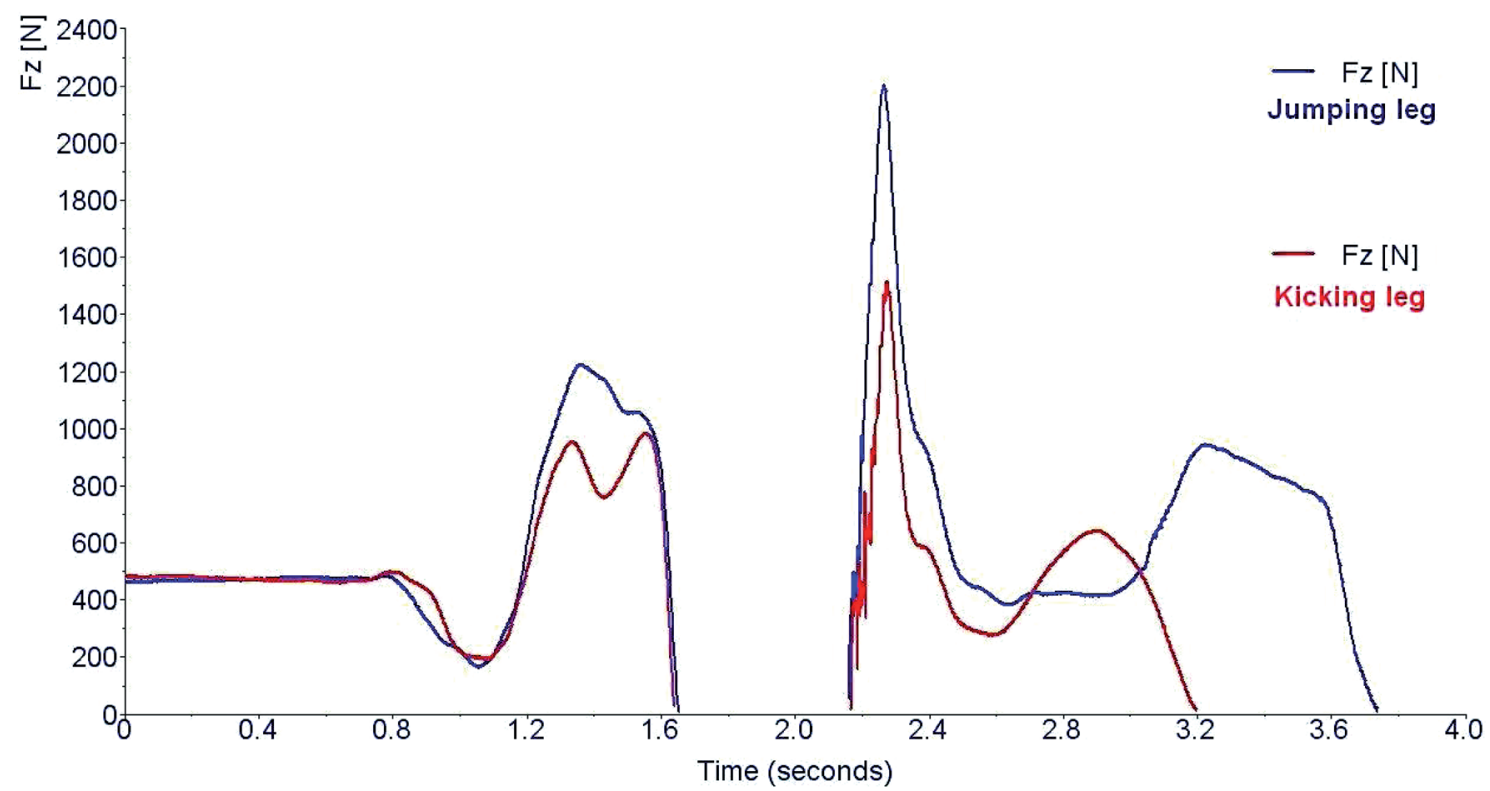

Figure 2. The force curves of asymmetric jump performance for jumping and kicking leg

in peak force between limbs $7.95 \%$ which is comparable with the difference we detected (7.06\%). Menzel et al. (2013) present in 46 soccer players a lower value (5.58\%). However, comparison of our results with the population of elite goalkeepers is not possible since we have not found any study presenting such research data.

In our study the force exerted in $\mathrm{CMJ}_{\mathrm{FA}}$ and $\mathrm{CMJ}$ was very similar; however, there is a significant difference between them and SJ. In the third type, only concentric work is used and therefore it has the lowest values in terms of absolute vertical jump values. The results indicate that for achieving absolute values of the jump, it is necessary to reduce the time between the braking and accelerating impulses. It could be improved by plyometric exercise, which can be an effective tool for the improvement of explosive power (Lehnert, Lamrová, \& Elfmark, 2009). In comparison of strength manifestation in our group with other authors (Häkkinen, 1991), these values are higher by $15 \%$; nevertheless, this is relative because it is necessary to relate this value to each participant's body weight and with- 
out knowledge of participants' body weight in other studies it is not possible to provide such a comparison. Many actions in soccer, including the jump, last for 250-300 ms and therefore a time aspect of force generation should be taken into account, hence the inclusion of force impulse and torque in the assessment of vertical jump is very important (Häkkinen, 1991; Kuangyou, 2008). From these results, it can be assumed that in achieving higher maximum vertical force component during the take-off, the transition phase from eccentric to concentric muscle action is more important than the use of arm swing at the take-off. Accumulated energy in the muscles of lower limbs can be used only for a limited time period; therefore it is essential that transition between eccentric and concentric phases is as short as possible. This knowledge should be taken into account in the training process so that appropriate type of exercise with the use of both principles of muscle work (concentric and eccentric) and their combination (eccentric-concentric) would be used.

Symmetry or asymmetry is very important for injury prevention, performance and postural stability (Vařeková, Vařeka, Janura, Svoboda, \& Elfmark, 2011). It is very difficult to find and set the most important moment for symmetrical evaluation between kicking leg and jumping leg. It is necessary take into consideration that the jump is a dynamic process and level of symmetry or asymmetry could be change during that process. That is why it will be necessary to analyse the whole force curve to determine the most important symmetry parameter on the take-off strength curve.

In our research, the highest asymmetry was found in $\mathrm{CMJ}_{\mathrm{FA}}$ jump and the difference between the limbs was $8.61 \pm 5.33 \%$. The difference in CMJ test was lower $(7.06 \pm 5.55 \%)$ and the lowest asymmetry was detected in $\mathrm{SJ}(3.95 \pm 3.48 \%)$. Significantly higher asymmetry in $\mathrm{CMJ}_{\mathrm{FA}}$ and $\mathrm{CMJ}$ tests was probably caused by more demanding action in terms of coordination (movement and timing of upper limb swing, countermovement of lower limbs) and stronger adaptation mechanism of jumping leg in goalkeeper's specific movements.

Fitness coaches and doctors suppose that greater muscle asymmetry between the limbs increases the risk of injury. More attention should be paid to individuals whose difference between the limbs is > 15\% (Croisier et al., 2003; Malý, Zahálka, \& Malá, 2010; Menzel et al., 2013). Occurrence of muscle asymmetry may be a result of insufficiently compensated physical activity, inadequate or incomplete rehabilitation programme, muscular strength imbalance between agonist and antagonist, long-term unilateral load (preferring) of one limb.

\section{CONCLUSIONS}

For measurement and assessment of explosive power of lower limbs, we selected a specific group of elite soccer players, goalkeepers, who are expected to cope better with this specific motor skill. The results showed that the observed groups were homogeneous in the measured parameters and that explosive strength in soccer goalkeepers at the top level is comparable. The best results of jump height were achieved, as expected, in the countermovement jump with arm swing $\left(\mathrm{CMJ}_{\mathrm{FA}}\right)$. In $\mathrm{CMJ}_{\mathrm{FA}}$ and $\mathrm{CMJ}$ tests, there was a significantly higher asymmetry in force exerted in the take-off phase than in SJ test. For more detail, observation of lower limbs separate participation during the vertical jump evaluation of the whole force curve is needed (calculation of braking or acceleration force impulse). Effective vertical jump requires good level of lower limb power and good movement pattern as motor skill. Both parts, power of lower limbs and power of core together with the movement could be trained and increased.

Monitoring of power level and strength asymmetries at the beginning of the preparatory phase enables identification of possible strength imbalances in elite SGs, which should be further reduced during the preparatory period. Screening examination of strength asymmetry may be thus a useful tool for both performance and injury prevention in SGs. Precise determination and quantification of strength asymmetries is essential for determination of the fundamental level of organized and intentionally controlled training process and for early compensation of the found imbalances. Despite the published results, there are still many unclear issues in this field which deserve further research. Comparison of strength asymmetries using different methods (jump test, isokinetic dynamometry), field tests (multiple hop test, change of direction on the preferred and no preferred leg), between different performance categories, gender, age, etc. is desirable in further research. It is surprising that despite a great number of scientific studies dealing with soccer, only a tiny part of research data is published about goalkeepers (most often as a secondary problem).

\section{ACKNOWLEDGEMENT}

This study was supported by grants VZ MSM 0021620864, GAČR P407/11/P784, and PRVOUK 038 .

\section{REFERENCES}

Bobbert, M. F., Gerritsen, K. G., Litjens, M. C. A., \& Van Soest, A. J. (1996). Why is the countermovement jump height greater than squat jump 
height? Medicine \& Science in Sport \& Excercise, 28, 1402-1412.

Boone, J., Vaeyens, R., Steyaert, A., Bossche, L. V., \& Bourgois, J. (2012). Physical fitness of elite Belgian soccer players by player position. Journal of Strength and Conditioning Research, 26(8), 2051-2057.

Cometti, G., Maffiuletti, N. A., Pousson, M., Chatard, J. C., \& Maffulli, N. (2001). Isokinetic strength and anaerobic power of elite, subelite and amateur French soccer players. International Journal of Sports Medicine, 22(1), 45-51.

Croisier, J. L., Reveillon, V., Ferret, J. M., Cotte, T., Genty, M., Popovich, N., . . .Crielaard, J. M. (2003). Isokinetic assessment of knee flexors and extensors in Professional soccer players. Isokinetics and Exercise Science, 11, 61-62.

Dauty, M., \& Potiron-Josse, M. (2004). Correlation and differences of performance between soccer players, professional, young players and amateurs, from the 10 meters sprint test and knee isokinetic assessment. Science \& Sports, 19, 75-79.

Fousekis, K., Tsepis, E., \& Vagenas, G. (2010). Lower limb strength in professional soccer players: Profile, asymmetry, and training age. Journal of Sports Science and Medicine, 9, 364-373.

Fowler, N. E., \& Reilly, T. (1993). Assessment of muscle strength assymmetry in soccer players. In E. J. Lovesey (Ed.), Contemporary Ergonomics (pp. 327-332). London: Taylor \& Francis.

Häkkinen, K. (1991). Force production characteristics of leg extensor, trunk flexor and extensor muscle in male and female basketball players. Journal of Sports Medicine and Physical Fitness, 31(3), 325-331.

Harriss, J. A., \& Atkinson, D. (2011). Update - ethical standards in sport and exercise science research. International Journal of Sports Medicine, 32, 819-821.

Haughen, T. A., Tønnessen, E., \& Seiler, S. (2013). Anaerobic performance testing of professional soccer players 1995-2010. International Journal of Sports Physiology and Performance, 8, 148-156.

Impellizzeri, F. M., Rampinini, E., Maffiuletti, N. A., \& Marcora, S. M. (2007). A vertical jump force test for assessing bilateral strength asymmetry in athletes. Medicine \& Science in Sport \& Excercise, 39(11), 2044-2050.

Ioannis, G. (2013). Comparison of physical capacities strength and speed of different competition level football players. Journal of Physical Education and Sport, 13(2), 255-259.

Janura, M., Vaverka, F., \& Elfmark, M. (1996). A comparison between the kinematic characteristics of the transition phase of ski jumping on jumping hills with different critical points. In T. Bauer (Ed.), ISBS 1995 Proceedings - XIII International Sym- posium for Biomechanics in Sport (pp. 219-222). Thunder Bay: Lakehead Univ Bookstore.

Kellis, S., Gerodimos, V., Kellis, E., \& Manou, V. (2001). Bilateral isokinetic concentric and eccentric strength profiles of the knee extensor and flexors in young soccer players. Isokinetics and Exercise Science, 9, 31-39.

Kraemer, W. J., \& Looney, D. P. (2012). Underlying mechanisms and physiology of muscular power. Strength and Conditioning Journal, 34(6), 13-19.

Kuangyou, B. (2008). The relationship between point strenght and standing vertical jump performance. Journal of Applied Biomechanics, 24, 224-233.

Kuruganti, U., \& Seaman, K. (2006). The bilateral leg strength deficit is present in old, young and adolescent females during isokinetic knee extension and flexion. European Journal of Applied Physiology, 97, 322-326.

Lehance, C., Binet, J., Bury, T., \& Croisier, J. L. (2009). Muscular strength, functional performances and injury risk in professional and junior elite soccer players. Scandinavian Journal of Medicine \& Science in Sports, 19, 243-251.

Lehnert, M., Lamrová, I., \& Elfmark, M. (2009). Changes in speed and strength in female volleyball players during and after a plyometric training program. Acta Universitatis Palackianae Olomucensis. Gymnica, 39(1), 59-65.

Lehnert, M., Urban, J., Procházka, J. H., \& Psotta, R. (2011). Isokinetic strength of knee flexors and extensors of adolescent soccer players and its changes based on movement speed and age. Acta Universitatis Palackianae Olomucensis. Gymnica, 41(2), 45-53.

Malý, T., Zahálka, F., \& Malá, L. (2010). Isokinetic strength, ipsilateral and bilateral ratio of peak muscle torque in knee flexors and extensors in elite young soccer players. Acta Kinesiologica, 4(2), 14-23.

Malý, T., Zahálka, F., \& Malá, L. (2011). Differences between isokinetic strength characteristic of more and less successful professional soccer teams. Journal of Physical Education and Sport, 11(3), 306-312.

Menzel, H. J., Chagas, M. H., Szmuchrowski, L. A., Araujo, S. R. S., Andrade, A. G. P., \& Jesus-Moraleida, F. R. (2013). Analysis of lower limb asymmetries by isokinetic and vertical jump tests in soccer players. Journal of Strength and Conditioning Research, 27(5), 1370-1377.

Rahnama, N., Lees, A., \& Bambaecichi, E. (2005). A comparison of muscle strength and flexibility between the preferred and non-preferred leg in English soccer players. Ergonomics, 48, 1568-1575.

Rahnama, N., Reilly, T., Lees, A., \& Graham-Smith, P. (2003). Muscle fatigue induced by exercise simulat- 
ing the work rate of competitive soccer. Journal of Sports Sciences, 21, 933-942.

Reiser, R., Rocheford, E., \& Armstrong, C. (2006). Building a better understanding of basic mechanical principles through analysis of the vertical jump. Strength and Conditioning Journal, 28(4), 70-80.

Svoboda, Z., Janura, M., Cabell, L., \& Janurová, E. (2009). Kinematic analysis of the flight phase of the Nordic combined and ski jump on a large hill (HS-134 m) during the 2009 Nordic World Ski Championships. Acta of Bioengineering and Biomechanics, 13(1), 19-25.

Tourny-Chollet, C., Leroy, D., Leger, G., \& Beuret-Blanquart, F. (2000). Isokinetic knee muscle strength of soccer players according to their position. Isokinetic and Exercise Science, 8, 187-193.

Vařeková, R., Vařeka, I., Janura, M., Svoboda, Z., \& Elfmark, M. (2011). Evaluation of postural asymmetry and gross joint mobility in elite female volleyball athletes. Journal of Human Kinetics, 13, 332-339.

Ziv, G., \& Lidor, R. (2010). Verical jump in female and male basketball players - A review of observational and experimental studies. Journal of Science and Medicine in Sport, 13, 332-339.

\section{HODNOCENÍ SILOVÉHO PROJEVU DOLNÍCH KONČETIN A SILOVÉ ASYMETRIE U FOTBALOVÝCH BRANKÁR̆Ů}

(Souhrn anglického textu)

VÝCHODISKA: Efektivní provedení vertikálního výskoku závisí na explozivní síle dolních končetin a jejich symetrickém zapojení. Hodnocení bilaterality dolních končetin je u fotbalových hráčů důležité především z pohledu prevence před zraněním.

ÚVOD: Cílem práce bylo identifikovat a porovnat parametry síly dolních končetin při třech různých typech testů výskoků u brankářů elitní úrovně. Dalším cílem bylo popsat a porovnat silové asymetrie zapojení dolních končetin během odrazové fáze při všech typech výskoku.

METODA: Výzkumná skupina byla tvořena 25 fotbalovými brankáři elitní úrovně (věk 26,5 9, 1 roku, výš- ka $186,1 \pm 7,8 \mathrm{~cm}$, hmotnost $86,7 \pm 14,8 \mathrm{~kg}$ ). Na dvou silových deskách byly realizovány tři typy vertikálního výskoku - výskok s pomocí horních končetin (countermovement jump with free arms - $\mathrm{CMJ}_{\mathrm{FA}}$ ), výskok bez pomoci horních končetin (countermovement jump - CMJ) a výskok z podřepu (squat jump - SJ). Hodnocené parametry byly - maximální síla během odrazu $\mathrm{F}_{\max }(\mathrm{N})$ a její relativní hodnota $\mathrm{F}_{\text {rel }}\left(\mathrm{N} \cdot \mathrm{kg}^{-1}\right)$, výška výskoku $\mathrm{h}(\mathrm{m})$ a silová asymetrie mezi dolními končetinami $\left(\Delta \mathrm{F}_{\max }\right)$. Pro statistickou analýzu byla použita metoda RM ANOVA.

VÝSLEDKY: Typ výskoku měl signifikantní efekt na výšku výskoku $\left(F_{2,48}=109,66, p<0,01, \eta^{2}=0,82\right)$. Nejvyšších výskokủ bylo dosaženo při výskoku s pomocí horních končetin $\mathrm{CMJ}_{\mathrm{FA}}$. Tento výsledek byl o 11,1\% $(5,01 \mathrm{~cm})$ vyšší ve srovnání s výskokem bez pomoci horních končetin CMJ a o 19,9 \% vyšší než při výskoku z podřepu SJ. Typ výskoku signifikantně ovlivňuje maximální sílu $\mathrm{F}_{\text {max }}\left(F_{1,6,38,7}=44,29, p<0,01, \eta^{2}=0,65\right)$ a relativní sílu $\mathrm{F}_{\text {rel }}\left(F_{2,48}=50,33, p<0,01, \eta^{2}=0,68\right)$. Silová asymetrie mezi dolními končetinami $\left(\Delta \mathrm{F}_{\max }\right)$ byla signifikantně rozdílná vzhledem k typu realizovaného výskoku $\left(F_{1,3,31,7}=5,14, p<0,05, \eta^{2}=0,18\right)$. Nejvyšší silová asymetrie byla zjištěna u výskoku s pomocí horních končetin $\mathrm{CMJ}_{\mathrm{FA}}\left(\Delta \mathrm{F}_{\max }=8,61 \%\right)$, zatímco u výskoku bez pomoci horních končetin $\mathrm{CMJ}$ byla asymetrie $\left(\Delta \mathrm{F}_{\max }=7,06 \%\right)$ a výskoku $\mathrm{z}$ podřepu $\mathrm{SJ}\left(\Delta \mathrm{F}_{\max }=3,95 \%\right)$. Byl nalezen signifikantní rozdíl u parametru $\Delta \mathrm{F}_{\max }$ mezi výskoky s pomocí horních končetin $\mathrm{CMJ}_{\mathrm{FA}}$ a výskoky z podřepu $\mathrm{SJ}(p<0,05)$ a u výskoků bez pomoci horních končetin CMJ a výskoků z podřepu $\mathrm{SJ}(p<0,01)$.

ZÁVĚRY: Nejvyšších výskoků bylo podle očekávání dosaženo při výskoku s pomocí horních končetin $\mathrm{CMJ}_{\mathrm{FA}}$, ale prri tomto typu výskoku bylo dosaženo i největších silových asymetrií mezi končetinami. Sledování výkonnostní úrovně a silových asymetrií na začátku přípravného období napomáhá identifikovat u elitních fotbalových brankářů silové dysbalance. Sledování projevů silových asymetrií by mělo být důležitou součástí pro hodnocení výkonu a prevence zranění u fotbalových brankářů.

Kličová slova: vertikální výskok, brankár, fotbal, symetrie, dysbalance, prevence zranění. 